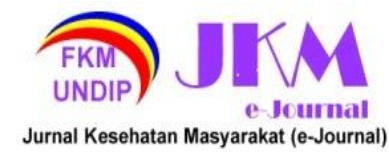

JURNAL KESEHATAN MASYARAKAT (e-Journal)

Volume 9, Nomor 6, November 2021

ISSN: 2715-5617 / e-ISSN: 2356-3346

http://ejournal3.undip.ac.id/index.php/jkm

\title{
FAKTOR-FAKTOR YANG BERPENGARUH TERHADAP KEIKUTSERTAAN POSYANDU LANSIA DI DESA GEDEGAN KECAMATAN TLOGOMULYO KABUPATEN TEMANGGUNG
}

\author{
Sinti Nurkholifah ${ }^{1}$, Atik Mawarniं ${ }^{2}$, Dharminto ${ }^{2}$ \\ ${ }^{1}$ Peminatan Biostatistika dan Kependudukan, Fakultas Kesehatan Masyarakat, Universitas \\ Diponegoro, Jl. Prof. H. Soedarto, S.H.,Tembalang, Semarang, Indonesia \\ ${ }^{2}$ Bagian Biostatistika dan Kependudukan, Fakultas Kesehatan Masyarakat, Universitas Diponegoro, \\ Jl. Prof. H. Soedarto, S.H.,Tembalang, Semarang, Indonesia \\ ${ }^{*}$ Corresponding author: sintinur026@gmail.com
}

\begin{abstract}
Elderly Posyandu is an Integrated Service Post that provides health services to elderly that organized by community. Gedegan village has one elderly Posyandu with low participation level. The purpose of this study to analyze factors that related the participation of Elderly Posyandu in Gedegan village, Tlogomulyo district, Temanggung regency. This research is an explanatory research with cross sectional design. Population of 316 people and research sample of 74 elderly. Data analyze by univariate test, bivariate and multivariate. The research result are majority of respondents were elderly $43,9 \%$, the most education was elementary school $41,9 \%$, the majority were still working $86,5 \%$, the majority lived with children/families $70,3 \%$, the respondents who participated were only $31,1 \%$. The result showed there are relationship between distance ( $p$-value $=0,038 ; O R=0,040$ ), perception of activities ( $p$-value $=0,004 ; O R=22,372$ ) and family support ( $p$-value $=0,009 ; O R=7,420$ ) to the participation of Elderly Posyandu. Recommended to increase the participation of elderly and family support, improve perceptions about Posyandu and change the hours of Posyandu activity outside working hours.
\end{abstract}

\section{Keywords : Elderly, Posyandu, Participation of elderly Posyandu}

\section{PENDAHULUAN}

Pos Pelayanan Terpadu (Posyandu) Lansia adalah suatu wadah pelayanan kesehatan bersumber daya masyarakat (UKBM) untuk melayani dan memberdayakan penduduk lansia. ${ }^{1}$ Ditinjau dari aspek kesehatan, kelompok usia lanjut akan mengalami penurunan derajat kesehatan baik secara alamiah maupun penyakit. Sehingga keakifan masyarakat usia lanjut untuk memanfaatkan Posyandu Lansia akan dapat membantu dalam menjaga kesehatan lansia sehingga dapat memperpanjang Usia Harapan Hidup (UHH). ${ }^{2}$ Usia Harapan Hidup (UHH) menjadi salah satu indikator keberhasilan pembangunan Indonesia, terutama di bidang kesehatan. Bangsa yang sehat ditandai dengan semakin panjangnya Usia Harapan Hidup penduduknya. ${ }^{3}$

Menurut WHO, usia lanjut dibagi dalam beberapa kelompok yaitu middle age yaitu 4559 tahun, elderly yaitu 60-74 tahun, old yaitu 75-90 tahun dan very old yaitu diatas 90 tahun. Kegiatan pelayanan posyandu lansia mempunyai dua sasaran yaitu sasaran langsung dan tidak langsung. Sasaran langsung terdiri dari kelompok pra lansia (45-59 tahun), lansia (60-69 tahun) dan lansia dengan risiko tinggi (> 70 tahun), sasaran tidak langsung terdiri dari keluarga, organisasi sosial dan masyarakat luas. ${ }^{4}$

Berdasarkan data Badan Pusat Statistik, usia harapan hidup penduduk Indonesia tahun 2018 adalah 73,19 tahun untuk perempuan dan 69,3 tahun untuk laki-laki yang diperkirakan akan selalu meningkat setiap tahunnya, ${ }^{5}$ hal ini berdampak pada peningkatan jumlah penduduk usia lanjut. Pada tahun 2017, jumlah penduduk usia lanjut di Jawa Tengah sebesar $12,59 \%$ atau 34,26 juta jiwa, ${ }^{6}$ jumlah penduduk usia lanjut di Kabupaten Temanggung sebesar $12,78 \%$ atau 97.085 jiwa. ${ }^{7}$ Kabupaten Temanggung terdiri dari beberapa kecamatan dimana setiap kecamatan mempunyai posyandu lansia. Cakupan pelayanan kesehatan usia lanjut di Kabupaten Temanggung pada tahun 2017 sebesar 73,53\%, masih di bawah target capaian SPM yaitu 100\%. Salah satu kecamatan yaitu Tlogomulyo, cakupan pelayanan kesehatan usia lanjutnya mengalami penurunan pada tahun 2017.8 Berdasarkan data dari Puskesmas Tlogomulyo, kehadiran posyandu lansia di wilayah kerjanya dari bulan Maret sampai dengan Mei mengalami kenaikan akan tetapi masih dibawah target $100 \%$ yaitu pada bulan Maret $=$ $6,4 \%$, April $=8 \%$ dan Mei $2019=9,60 \%$. Desa 


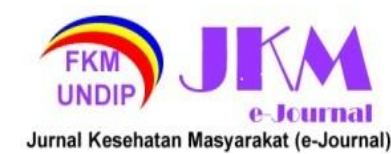

Gedegan adalah salah satu desa di wilayah kerja puskesmas Tlogomulyo yang angka kunjungan posyandu lansianya masih rendah di bandingkan posyandu lainnya.

Menurut Lawrence Green, faktor yang mempengaruhi perilaku kesehatan antara lain yaitu faktor predisposisi, faktor pemungkin dan faktor penguat. ${ }^{9}$ Penelitian Sundari dan Mentari (2015) memberikan hasil dukungan keluarga berhubungan signifikan dengan keaktifan lansia pada posyandu lansia. ${ }^{10}$ Penelitian Frans Juniardi (2013) memberikan hasil bahwa jarak tempat tinggal dengan lokasi mempengaruhi minat lansia mengikuti posyandu. ${ }^{11}$ Faktor lainnya yaitu persepsi, menurut penelitian Sartyka Laya (2019) terdapat hubungan signifikan antara persepsi dengan pemanfaatan posyandu lansia di Kelurahan Limba Kota Gorontalo. Persepsi yang baik mengenai kegiatan di posyandu maka akan meningkatkan minat lansia untuk mengunjungi posyandu. ${ }^{12}$ Berdasarkan uraian diatas, maka akan dilakukan penelitian dengan tujuan menganalisis faktor-faktor yang berhubungan dengan keikutsertaan posyandu lansia di Desa Gedegan Kecamatan Tlogomulyo Kabupaten Temanggung.

\section{METODOLOGI PENELITIAN}

Penelitian ini merupakan penelitian explanatory research dengan pendekatan cross sectional study. Populasi penelitian adalah sasaran posyandu lansia di desa Gedegan yang berjumlah 316 orang. Sebagai populasi adalah sasaran posyandu lansia di desa Gedegan yaitu masyarakat yang berumur mulai dari 45 tahun yang berjumlah 316 orang. Pemilihan sampel dilakukan secara proporsional random sampling, perhitungan sampel menghasilkan sampel sebanyak 74 lansia. Pengumpulan data menggunakan kuesioner yang telah diuji validitas dan reliabilitas. Analisis data dilakukan secara univariat, bivariat dan multivariat.

\section{HASIL DAN PEMBAHASAN}

Analisis Univariat

Analisis univariat digunakan untuk mendeskripsikan karakteristik responden sesuai tabel 1.

Tabel 1. Distribusi Frekuensi Karakteristik Responden

\begin{tabular}{clll}
\hline No & $\begin{array}{l}\text { Karakter } \\
\text { Responden }\end{array}$ & $\mathbf{n}$ & $\%$ \\
\hline 1 & $\begin{array}{l}\text { Kelompok Umur : } \\
\text { Pra Lansia (45-59 } \\
\text { tahun) }\end{array}$ & 31 & 41,9 \\
& & &
\end{tabular}

KESEHATAN MASYARAKAT (e-Journal)

Volume 9, Nomor 6, November 2021

ISSN: 2715-5617 / e-ISSN: 2356-3346

http://ejournal3.undip.ac.id/index.php/jkm

\begin{tabular}{|c|c|c|}
\hline \multirow{2}{*}{\multicolumn{3}{|c|}{$\begin{array}{l}\text { Lanjut Usia }(60- \\
74 \text { tahun) }\end{array}$}} \\
\hline & & \\
\hline $\begin{array}{l}\text { Lanjut Usia Tua } \\
\text { (75-90 tahun) }\end{array}$ & 9 & 12,2 \\
\hline \multicolumn{3}{|l|}{ Jenis Kelamin : } \\
\hline Perempuan & 49 & 66,2 \\
\hline \multicolumn{3}{|l|}{ Pendidikan } \\
\hline \multicolumn{3}{|l|}{ Terakhir : } \\
\hline Tidak Sekolah & 12 & 16,2 \\
\hline Tidak Tamat SD & 28 & 37,8 \\
\hline Tamat SD & 31 & 41,9 \\
\hline Tamat SMP & 3 & 4,1 \\
\hline \multicolumn{3}{|l|}{ Status Pekerjaan : } \\
\hline Tidak Bekerja & 10 & 13,5 \\
\hline Bekerja & 64 & 86,5 \\
\hline Status & & \\
\hline $\begin{array}{l}\text { Tinggal : } \\
\text { Rumah }\end{array}$ & 18 & 24,3 \\
\hline Suami/Istri & & \\
\hline Rumah & 52 & 70,3 \\
\hline Anak/keluarga & & \\
\hline Rumah Cucu & 1 & 1,4 \\
\hline Rumah Sendiri & 22 & 29,3 \\
\hline Keikutsertaan & & \\
\hline Posyandu Lansia & & \\
\hline Ikut & $\begin{array}{l}23 \\
51\end{array}$ & 31,1 \\
\hline & & \\
\hline
\end{tabular}

Sesuai tabel 1 responden terbanyak masuk pada katagori pra lansia $41,9 \%$ dan lansia $43,9 \%$, hanya $14,9 \%$ yang masuk katagori lansia dengan risiko tinggi. Pendidikan responden yang tamat SD $41,9 \%$, terkecil adalah tamat SMP $4,1 \%$ dan masih ada yang tidak sekolah 16,2\%. Sebagian besar responden masih bekerja $86,5 \%$, sebagian besar tinggal bersama keluarganya $70,3 \%$. Responden yang ikut kegiatan posyandu lansia hanya $31,1 \%$.

\section{Analisis Bivariat}

Menggunakan Uji Chi Square, analisis bivariat digunakan untuk mengetahui hubungan variabel bebas dengan variabel terikat.

Tabel 2. Hubungan Variabel Bebas dengan Keikutsertaan Posyandu Lansia

\begin{tabular}{|c|c|c|c|c|c|c|c|}
\hline \multirow[t]{3}{*}{ Variabel } & \multicolumn{4}{|c|}{$\begin{array}{l}\text { Keikutsertaan } \\
\text { Posyandu } \\
\text { Lansia }\end{array}$} & \multirow{2}{*}{\multicolumn{2}{|c|}{ Total }} & \multirow{3}{*}{$\begin{array}{l}p \\
\text { valu } \\
e\end{array}$} \\
\hline & \multicolumn{2}{|c|}{ Ikut } & \multicolumn{2}{|c|}{$\begin{array}{c}\text { Tidak } \\
\text { Ikut }\end{array}$} & & & \\
\hline & $n$ & $\%$ & $\mathrm{n}$ & $\%$ & $n$ & $\%$ & \\
\hline $\begin{array}{l}\text { Pengeta } \\
\text { huan }\end{array}$ & & & & & & & 0,00 \\
\hline Baik & $\begin{array}{l}2 \\
1\end{array}$ & $\begin{array}{r}53 \\
, 8\end{array}$ & $\begin{array}{l}1 \\
8\end{array}$ & $\begin{array}{r}46 \\
\text {,2 }\end{array}$ & $\begin{array}{l}3 \\
9\end{array}$ & $\begin{array}{c}10 \\
0\end{array}$ & 01 \\
\hline
\end{tabular}




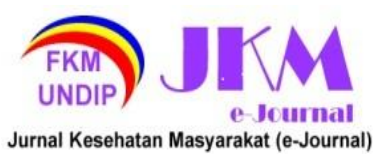

$\begin{array}{lrrrrrrr}\text { Kurang } & 2 & 5, & 3 & 94 & 3 & 10 & \\ & & 7 & 3 & , 3 & 5 & 0 & \\ \text { Persepsi } & & & & & & & \\ \text { Baik } & 2 & 53 & 1 & 46 & 3 & 10 & 0,00 \\ & 1 & , 8 & 8 & , 2 & 9 & 0 & 01 \\ \text { Kurang } & 2 & 5, & 3 & 94 & 3 & 10 & \\ & & 7 & 3 & , 3 & 5 & 0 & \end{array}$

Kondisi

Fisik

\begin{tabular}{lrrrrrrl} 
Baik & 4 & 15 & 2 & 84 & 2 & 10 & 0 \\
& & 4 & 2 &, 6 & 6 & 0 & \\
Kurang & 1 & 39 & 2 & 60 & 4 & 10 & \\
& 9 &, 6 & 9 &, 4 & 8 & 0 & \\
Jarak & & & & & & & \\
$\quad$ Dekat & 1 & 26 & 4 & 73 & 6 & 10 & 0,02 \\
& 8 &, 9 & 9 &, 1 & 7 & 0 & 7 \\
Jauh & 5 & 71 & 2 & 28 & 7 & 10 & \\
& &, 4 & &, 6 & & 0 & \\
Dukunga & & & & & & & \\
n & & & & & & & 0,00 \\
Keluarga & & & & & & & 01 \\
Baik & 2 & 54 & 1 & 45 & 3 & 10 & \\
& 0 &, 1 & 7 &, 9 & 7 & 0 & \\
Kurang & 3 & 8, & 3 & 91 & 3 & 10 & \\
& & 1 & 4 &, 9 & 7 & 0 & \\
\hline
\end{tabular}

Sesuai tabel 2 terdapat hubungan antara pengetahuan dengan keikutsertaan posyandu lansia $(p=0,0001)$. Tingkat pengetahuan mampu mendorong lansia untuk ikut maupun tidak ikut dalam kegiatan posyandu lansia. Pada penelitian ini lansia yang ikut kegiatan posyandu lansia sebagian mempunyai pengetahuan yang sudah baik $(58,8 \%)$. Sedangkan yang tidak ikut kegiatan posyandu lansia sebagian besar pengetahuannya kurang $(94,3 \%)$. Sejalan dengan penelitian Purnawati (2014), terdapat hubungan antara pengetahuan dengan kunjungan lansia ( $p$ value $=0,001$ ). Lansia yang ikut serta dalam posyandu lansia sebagian besar mempunyai pengetahuan baik. ${ }^{13}$ Pengetahuan merupakan faktor penting dalam membentuk tindakan seseorang. Perilaku yang dilakukan seseorang akan bertahan lama apabila didasari oleh pengetahuan, kesadaran dan sikap yang positif pada perilaku tersebut. ${ }^{14}$ Terkait dengan persepsi yang didefinisikan sebagai pengalaman yang dihasilkan melalui indera manusia dimana setiap individu mempunyai persepsi atau pandangan yang berbeda dengan orang lain pada satu objek yang sama. ${ }^{14}$ Uji chi square memberikan hasil terdapat hubungan yang bermakna antara persepsi posyandu lansia dengan keikutsertaan posyandu lansia ( $p$ value $=0,0001$ ). Lansia yang mengikuti kegiatan posyandu lansia sebagian mempunyai persepsi yang baik terhadap posyandu lansia $(53,8 \%)$ sedangkan lansia yang tidak ikut posyandu lansia sebagian besar mempunyai persepsi kurang baik (94,3\%). Penelitian Sudaryanto (2018) juga memberikan hasil yang sama yaitu ada hubungan antara variabel persepsi dengan kehadiran lansia dalam kegiatan pembinaan posyandu di Puskesmas Prambanan 1 Yogyakarta. Adanya kaitan persepsi kesehatan akan mempengaruhi seseorang dalam mengambil keputusan atau tindakan selanjutnya. Seseorang bisa bertindak yaitu mau memanfaatkan pelayanan kesehatan didasarkan atas sejauh mana tindakan tersebut bernilai untuk dirinya ${ }^{10}$ Adanya kualitas pelayanan atau kegiatan yang baik akan membentuk persepsi yang baik pula, sehingga bersedia mengikuti dan akan datang kembali ke posyandu pada bulan berikutnya. ${ }^{15}$

Keterkaitan antara kondisi fisik dengan keikutsertaan posyandu lansia, diperoleh $p$ value $=0,060$ yang dapat diartikan tidak ada hubungan antara dua variabel tersebut. Tidak adanya hubungan antara kondisi fisik lansia dengan keikutsertaan posyandu lansia dikarenakan masyarakat usia lanjut baru akan mengikuti posyandu apabila dirinya mengalami keluhan pada kesehatannya. Sedangkan tujuan dari pembinaan posyandu tidak hanya untuk mengobati namun juga meningkatkan dan mengontrol kesehatan lansia. Adanya persepsi yang masih buruk terhadap pentingnya prinsip pencegahan pada kegiatan posyandu lansia menyebabkan lansia cenderung memilih tidak mengikuti kegiatannya. Jadi, kondisi fisik tidak mempengaruhi keputusan lansia untuk hadir dalam kegiatan posyandu lansia. Berbeda dengan penelitian Junianto yaitu terdapat hubungan antara keaktifan dengan status kesehatan lansia ( $p$ value $=0,0001)$. Lansia tidak mengikuti posyandu dikarenakan faktor sosial dan pertambahan usia yang menyebabkan melemahnya fisik dan kesehatan lansia sehingga enggan untuk datang ke posyandu. ${ }^{16}$ Lansia yang tidak sehat akan tergantung pada orang lain sedangkan lansia yang sehat akan memudahkannya untuk beraktivitas seperti mengurus dirinya sendiri, rekreasi, bekerja, memeriksakan kesehatan maupun hadir dalam kegiatan posyandu. ${ }^{17}$

Jarak merupakan rentang antara tempat tinggal dengan tempat pelayanan kesehatan yang aksesibilitasnya dapat dilihat dari jarak tempuh, waktu tempuh dan juga sarana transportasi yang digunakan ${ }^{2}$. Jarak dekat adalah $<10$ menit atau $<1 \mathrm{~km}$ dari tempat tinggal menuju lokasi posyandu ${ }^{18}$. Hasil uji 


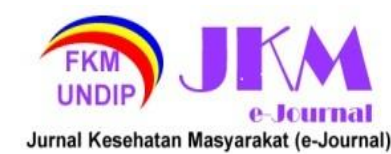

statistik didapatkan $p$ value 0,027 hal ini berarti terdapat hubungan antara jarak dengan keikusertaan posyandu lansia. Lansia yang tidak ikut sebagian besar jarak rumahnya dekat dengan posyandu $(73,1 \%)$ sedangkan untuk yang ikut sebagaian besar jarak rumahnya jauh dari posyandu $(71,4 \%)$. Sejalan dengan hasil penelitian Rusmin (2016) bahwa terdapat keterkaitan antara jarak ke pelayanan kesehatan dengan pemanfaatan posyandu lansia. Diperoleh sebanyak $45,5 \%$ yang mengatakan aksesnya sulit menuju lokasi posyandu namun sikapnya postitif. ${ }^{19}$

Dukungan keluarga merupakan pemberian dorongan minat atau kesediaan lansia oleh keluarganya untuk melakukan aktifitas atau membuat keputusan ${ }^{20} \mathrm{Uji}$ chi square memberkan hasil ada hubungan yang signifikan antara dukungan keluarga dengan keikutsertaan posyandu lansia ( $p$ value $=0,0001$ ). Berdasarkan tabulasi silang didapatkan bahwa kelompok yang ikut sebagian dari responden mempunyai dukungan keluarga yang baik $(54,1 \%)$ sedangkan kelompok yang tidak mengikuti posyandu sebagian besar dukungan keluarganya kurang baik $(91,9 \%)$. Sejalan dengan penelitian Aldriana (2015) bahwa terdapat hubungan antara dukungan keluarga dengan rendahnya kunjungan lansia ke posyandu lansia ( $p$ value $=0,0001$ ). Kunjungan posyandu lansia yang rendah disebabkan karena tidak ada dukungan dari keluarga yang mempunyai peranan penting pada keputusan lansia untuk memanfaatkan posyandu ataupun tidak. ${ }^{17}$ Keluarga yang sudah mengetahui manfaat pelayanan kesehatan posyandu mengharapkan petugas kesehatan untuk melayani dan merawat kesehatan lansia dengan baik. ${ }^{21}$ Dukungan dari keluarga yang diberikan kepada usia lanjut dapat berupa material, tenaga, pikiran, hiburan, semangat atau kepercayaan sehingga memotivasi lansia untuk memeriksa dan mengontrol kesehatannya. ${ }^{22}$

\section{Analisis Multivariat}

Analisis multivariat digunakan untuk mengetahui hubungan variabel bebas secara bersama-sama terhadap keikutsertaan Posyandu Lansia. Hasil terakhir dengan metode Backward Wald terdapat pada tabel 3 sebagai berikut:

Tabel 3. Hasil Analisis Regresi Logistik antara Variabel bebas dengan Keikutsertaan pada Posyandu Lansia

\begin{tabular}{lrrrrr}
\hline Variabel Bebas & B & Wald & P & Exp (B) & 95\% Cl \\
& & & & & \\
\hline Jarak & $-3,213$ & 4,320 & 0,038 & 0,040 & $0,002-0,833$ \\
Persepsi Kegiatan & 3,108 & 8,116 & 0,004 & 22,372 & $2,673-189,792$ \\
Dukungan Keluarga & 2,004 & 6,896 & 0,009 & 7,420 & $1,663-33,117$ \\
Constan & $-0,582$ & 1,920 & 0,166 & 0,559 & \\
\hline
\end{tabular}

Hosmer and Lemeshow ( $p$ value $=0,670$ )

Berdasarkan tabel 3 , terdapat hubungan jarak dengan keikutsertaan pada posyandu lansia $(\mathrm{p}=0,038 ; \mathrm{Cl}: 0,002-0,833$ ) dengan OR sebesar 0,04 . Hasil tersebut memberikan arti bahwa jarak tempat tinggal terhadap tempat posyandu lansia diselenggarakan merupakan faktor protektif terhadap keikutsertaan lansia, yang dapat diartikan lansia yang jarak tempat tinggalnya jauh berminat untuk datang ke posyandu, sebaliknya lansia yang jarak rumahnya dekat tidak berminat datang ke posyandu. Kondisi tersebut disebabkan lansia yang rumahnya dekat banyak yang bekerja, sementara itu kegiatan posyandu diselenggarakan pada jam kerja sehingga para lansia tidak dapat mengikuti kegiatan posyandu. Sejalan dengan penelitian Susanti tahun 2011 bahwa nilai Exp $(B)=0,263$ yang dapat diartikan jarak yang dekat lebih berisiko 0,263 kali untuk memanfaatkan posyandu lansia. Lansia yang tempat tinggalnya jauh lebih banyak yang memanfaatkan posyandu, dikarenakan mereka mempunyai perekonomian yang baik sehingga lebih memilih langsung berobat ke rumah sakit. ${ }^{23}$

Persepsi tentang kegiatan posyandu lansia memberikan $\mathrm{p}=0,004$ dengan ( $\mathrm{OR}=$ 22,$372 ; \quad \mathrm{Cl}=2,673-189,792$ ) yang dapat diartikan lansia yang mempunyai persepsi baik mempunyai pengaruh 22,372 lebih besar untuk mengikuti kegiatan posyandu dibandingkan yang persepsinya kurang. Sejalan dengan penelitian Lestari (2011) bahwa persepsi merupakan salah satu faktor yang mempengaruhi kunjungan lansia. Persepsi yang baik memiliki pengaruh 6,5 kali lebih besar untuk mengikuti posyandu lansia daripada persepsi buruk untuk aktif. ${ }^{24}$ 


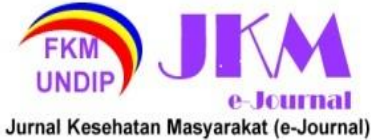

Dukungan keluarga menghasilkan $p$ value $=0,009$ dengan $(\mathrm{OR}=7,420 ; \mathrm{Cl}=1,663$ 33,117 ) yang dapat diartikan lansia yang mendapatkan dukungan keluarga baik pengaruhnya 7,4 kali lebih besar dibandingkan yang dukungan keluarganya kurang baik. Sejalan dengan penelitian Purnawati (2014) bahwa dukungan keluarga adalah faktor yang berpengaruh terhadap kunjungan posyandu lansia. Nilai OR sebesar 66,257 artinya lansia yang mempunyai dukungan baik cenderung untuk ikutserta dalam kegiatan posyandu. ${ }^{13}$

Dari semua variabel yang berhubungan dengan keikutsertaan posyandu lansia, faktor yang paling berpengaruh terhadap keikutsertaan posyandu adalah persepsi terhadap posyandu, yang selanjutnya diikuti dukungan keluarga dan jarak tempat tinggal ke posyandu. Sehingga untuk dapat meningkatkan kunjungan lansia ke posyandu perlu diperbaiki pesepsi tentang posyandu, peningkatan dukungan keluarga dan jam buka kegiatan posyandu

\section{KESIMPULAN}

Responden terbanyak masuk pada katagori pra lansia $41,9 \%$ dan lansia $43,9 \%$, hanya $14,9 \%$ yang masuk katagori lansia resti. Pendidikan terbanyak responden adalah tamat SD $41,9 \%$ dan tamat SMP $4,1 \%$ akan tetapi masih ada yang tidak sekolah $16,2 \%$. Sebagian besar responden masih bekerja $86,5 \%$, sebagian besar tinggal bersama anak/keluarga $70,3 \%$, responden yang ikut kegiatan posyandu lansia hanya $31,1 \%$. Lansia yang bekerja bertempat tinggal dekat dengan kegiatan Posyandu Lansia sehingga meskipun jarak rumahnya dekat akan tetapi tidak dapat mengikuti kegiatan posyandu yang jam bukanya pada waktu jam kerja. Uji regresi logistik memberikan hasil terdapat hubungan jarak rumah ke posyandu ( $p$ value $=0,038$ dan $\mathrm{OR}=0,040)$, persepsi kegiatan ( $p$ value $=$ 0,004 dan $\mathrm{OR}=22,372$ ) dan dukungan keluarga ( $p$ value $=0,009$ dan $\mathrm{OR}=7,420)$ terhadap keikutsertaan posyandu lansia.

\section{SARAN}

Disarankan untuk dapat meningkatkan keikutsertaan lansia pada posyandu lansia, perlu adanya perbaikan persepsi mengenai posyandu, meningkatkan dukungan keluarga dan mengubah jam kegiatan posyandu diluar jam kerja .

\section{REFERENSI}

1. Sari E. Gambaran Tingkat Pengetahuan Keluarga Tentang Posyandu Lansia Di
Puskesmas Pembantu Gunung Sari Surabaya. J Keperawatan. 2014;3(2):1-7.

2. Ningsih R. Faktor-Faktor yang Mempengaruhi Minat Lansia Mengunjungi Posyandu Lansia. Jom Psik. 2014;1(2):110.

3. Kemenkes RI. Situasi dan Analisis Lanjut Usia. Jakarta: Pusat Data dan Informasi Kementerian Kesehatan RI; 2014. 1-2 p.

4. Metkono YS, Nusawakan AW, Sujana T. Strategi Intervensi Lansia di Posyandu. IKESMA. 2017;13(1):59-67.

5. Badan Pusat Statistik. Output Tabel Dinamis: Angka Harapan Hidup (AHH) Menurut Provinsi dan Jenis Kelamin [Internet]. Badan Pusat Statistik; 2018. Available from: https://www.bps.go.id/dynamictable/2016/0 1/08 00:00:00//1114/angka-harapan-hidupahh-menurut-jenis-kelamin-dan-provinsi2010-2014.html

6. Badan Pusat Statistik. Profil Lansia Provinsi Jawa Tengah 2017. Semarang: Badan Pusat Statistik Provinsi Jawa Tengah; 2018. 16-20 p.

7. BPS Kabupaten Temanggung. Kabupaten Temanggung Dalam Angka 2018. Temanggung: Badan Pusat Statististik Kabupaten Temanggung; 2018. 36 p.

8. Dinkes Temanggung. Profil Kesehatan Tahun 2017 Kabupaten Temanggung. Temanggung: Dinas Kesehatan Kabupaten Temanggung; 2018.

9. Notoatmodjo S. Promosi Kesehatan Teori dan Aplikasinya. Revisi. Jakarta: Rineka Cipta; 2010.

10.Sundari S, Mentari P. Faktor-Faktor yang Berhubungan dengan Keikutsertaan Lansia dalam Posyandu Lansia. J Kesehat Komunitas [Internet]. 2015; Available from: http://jurnal.akbiduk.ac.id/assets/doc/17022 3083207-3.pdf

11.Juniardi F. Faktor-Faktor yang Mempengaruhi Rendahnya Kunjungan Lansia ke Posyandu Lansia di Puskesmas Batang Beruh Kecamatan Sidikalang Kabupaten Dairi. 2013;96.

12.Laya SK, Kadir S, Lansia P. The Interrelation Among Elderly Percption and Participation and the Utilization of Posyandu. J Heal Sci. 2019;1(1).

13.Purnawati N, Irdawati, Yuniartika W. FaktorFaktor yang Mempengaruhi Kunjungan Lansia dalam Kegiatan Posyandu di Desa Plumbon Kecamatan Mojolaban Sukoharjo. J eprints Univ Muhammadiyah S. 2014;

14. Notoatmodjo S. Promosi Kesehatan dan Perilaku Kesehatan. In Jakarta: Rineka 


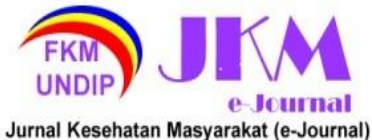

Cipta; 2012

15. Nugraha NA, Subekti I, Adi GS. Hubungan antara Jarak dan Kualitas Pelayanan dengan Pemanfaatan Posyandu Lansia di Wilayah Kerja Puskesmas Jatipuro Karanganyar. stikes kusuma husada. 2016;

16.Junianto D, Supriyadi, Walid S. Hubungan Keaktifan dengan Status Kesehatan Lansia di Posyandu Lansia Anggrek 02 Wilayah Kerja Puskesmas Sumberbaru Jember. Repos Univ Muhammadiyah Jember. 2017;42:1-10.

17. Aldriana N, Daulay R. Faktor - Faktor yang Berhubungan Dengan Rendahnya Kunjungan Lansia Ke Posyandu Lansia Di Desa Rambah Tengah Utara Wilayah Kerja Puskesmas Rambah Tahun 2015. J Matern Neonatal. 2016;2(2):91-101.

18. Liro AS, Indah DA, Andrianto A. Hubungan Aksesbilitas, Dukungan Keluarga dan Status Gizi Lansia dengan Pemanfaatan Posyandu Lansia. J Kesehat. 2016;4(3):5768.

19.Rusmin M, Bujawati E, Habiba N. FaktorFaktor yang Berhubungan dengan Pemanfaatan Posyandu Lansia di Wilayah Kerja Puskesmas Somba Opu Kabupaten Gowa Tahun 2015. Al-Sihah Public Heal Sci Jourrnal. 2017;9(2):9-18.

20.Suseno DM. Faktor-Faktor yang Mempengaruhi Keaktifan Lansia dalam Mengikuti Kegiatan Posyandu Lansia di Desa Kauman Kecamatan Polanharjo Kabupaten Klaten. Eprints UMS [Internet]. 2012; Available from: http://eprints.ums.ac.id/20530/28/2._NASK AH_PUBLIKASI.pdf

21. Simbolon $P$, Simbolon N. Association between Social-Cultural and the Utilization of Elderly Integrated Health Services (Posyandu Lansia) in Hamparan Perak Health Center. Unnes J Public Heal. 2018;7(1):50-4.

22. Yuspitasari, Anwar M, Hamilludin. Faktor yang Mempengaruhi Keaktifan Lansia dalam Kegiatan Pobindu di Kelurahan Madatte di Wilayah Kabupaten Polewali Mandar. J Kesehat Masy. 2017;3(1):24-36.

23. Susanti N, Mitra. Faktor-Faktor yang Posyandu Lansia Berhubungan dengan Pemanfaatan Pelayanan. J Kesehat Komunitas. 2011;1(3):155-62.

24. Lestari P, Hadisaputro S, Pranarka K. Beberapa Faktor yang Berperan Terhadap Keaktifan Kunjungan Lansia ke Posyandu. J Media Med Indones. 2011;45(5):74-82.
Volume 9, Nomor 6, November 2021

ISSN: 2715-5617 / e-ISSN: 2356-3346

http://ejournal3.undip.ac.id/index.php/jkm

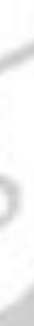
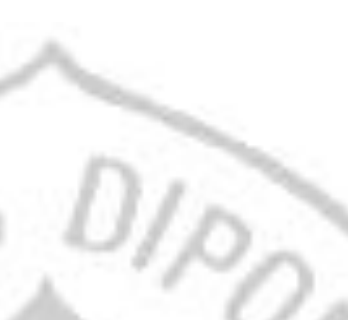

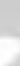

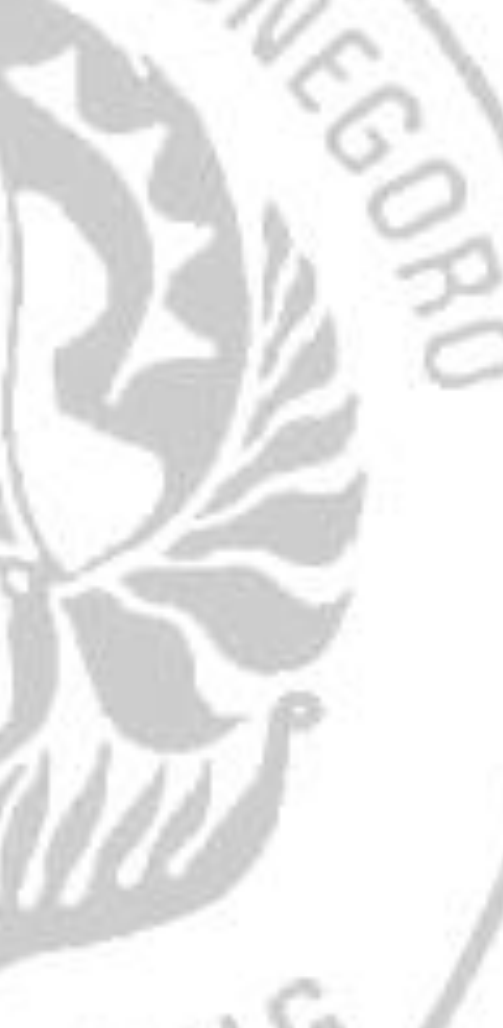

